\section{Bell Labs}

\section{From monopoly to competition}

Murray Hill, New Jersey

REPORTS of the death of research at AT\&T Bell Laboratories have been exaggerated. Since AT\&T spun off seven regional telephone operating companies representing two-thirds of its assets at the start of 1984 in settlement of an anti-trust case, Bell Laboratories have indeed changed. But fears that the new slimmeddown AT\&T would be unable or unwilling to support basic research in the style of the past have not materialized.

For 60 years, Bell Labs have been the world's foremost electronic research laboratories. Ian Ross, Bell Labs' president, argues that with a budget of $\$ 2,000$ million and a staff of 19,000 , the laboratories are of the scale expected of a company the size of AT\&T (operating revenues in 1984: $\$ 33,000$ million), and that basic research is now more important to AT\&T than ever. What has changed is that the development staff, representing (as it did before 1984) some 90 per cent of the total, is now working more efficiently and with increased urgency to exploit usable research results to develop what he calls "killer technologies": technologies that will, like the transistor, lead to the demise of what went before. Basic research, he insists, remains untouched.

The corporate restructuring has, however, been far from painless. In the year following divestiture, Bell Labs lost 4,000 of their then 24,000 staff to AT\&T information systems, which manufactures computers, and a further 4,000 to Bell Communications Research, the company set up to conduct research for the newly liberated local telephone companies. Some of the lost ground has since been regained, and Ross has used the opportunity to push Bell Labs in what he sees as the direction of AT\&T's future: "we are", he says, "running like hell to change the technology mix".

The 1982 settlement that led to the break-up of AT\&T also affirmed an earlier ruling of the Federal Communications Commission that allowed it to enter unregulated markets in informationhandling. Ross's greatest hope for Bell Labs is that they will achieve a "fundamental solution to the problem of how to handle software", in which progress worldwide has been less spectacular than in hardware. Almost half of Bell Labs' employees are now producing software as their end-product, and Ross expects to see the proportion rise.

The Strategic Defense Initiative (SDI) is one area that would benefit from fundamental software advances and Ross is making bids on SDI contracts. Solid-state physics and chemistry, once at the forefront of Bell Labs' research, are by com- parison now taking a back seat, while only a handful of researchers in economics and psychology remain to keep AT\&T with a "window" in that field.

Not that Ross has abandoned physics; there are, he says, still two orders of magnitude of improvement in the circuit density of silicon integrated circuits to be achieved before fundamental constraints are reached, and three orders of magnitude of improvement in optical data transmission rates. Ross clearly intends that Bell Labs should maintain their preeminence in this area.

But for all Ross's enthusiasm, it is plain that the uncertainty of 1984 did cause a crisis of morale among Bell Labs' researchers. The losses to Bell Communications Research (Bellcore) and AT\&T Information Systems were keenly felt; in Bell Labs' photonics research laboratory, for example, Bell Labs researchers work alongside Bellcore staff but are forbidden to share their research results. That irritation should soon be removed, when the Bellcore workers move into a new building now under construction. But AT\&T's uncertain finances, which have caused large lay-offs in some manufacturing divisions, have led to what Ross calls a "salary structure freeze" across the company, including Bell Labs, meaning that salary increases are not awarded automatically. Ross says the "expectation" is that salaries "will be unfrozen" before long.

Many researchers, however, go to work at Bell Labs in part because of their reputation for having an easy collegiate atmosphere with the freedom to pursue academic interests. The introduction of symbols of corporate formality such as security checks for visitors and identification badges for staff therefore caused much resentment, and some took the changes as a cue to leave, most to go to universities.

One who did leave Bell Labs, Terry Miller, went to become professor of chemistry at Ohio State University; he says his decision was the result of a tempting offer and uncertainty about the climate for research at Bell Labs, but he remains in contact with former colleagues and does not now hesitate to recommend a research career there to inquiring students.

Not all divisions seem to have experienced attrition. Kumar Patel, executive director of research for physics and academic affairs, noted no change, but said the changed circumstances of AT\&T meant that he had to "do more explaining" to hire promising researchers. But Patel's division has not been untouched by the changes to AT\&T. Physicists in the division have shown the possibility of building a positron microscope, which would be an analytical tool with unique properties. "In the old environment, we would have done nothing about it", said Patel. Now, development staff are watching progress closely, and within two years a business decision will be taken on whether the positron microscope should be the target of a major Bell Labs development effort.

Arno Penzias, Bell Labs' vice president for research, is clearly stung by suggestions that AT\&T's new competitive spirit will mean an end to the sort of unfettered basic research that led, for example, to his Nobel-prize-winning discovery of the cosmic microwave background radiation. Penzias defiantly points out that astrophysicists still work at Bell Labs, the justification being that the tools of their research may have applications to AT\&T's technological base. High-energy physicists, by the same logic, are not employed. And Penzias insists that basic research staff, who now number about 1,000 ("crudely where it's been for a long time") are still encouraged to pursue long-term projects that might bring benefits in five to 20 years rather than more short-term gains. Researchers realize that they are protected as far as possible from the effects of fluctuating budgets, and most feel the worst of the crisis is over.

Penzias says that long-term strategic research at Bell Labs has always been important because, even before divestiture and despite the appearance of monopoly, AT\&T always faced pressure to be competitive on prices. (Penzias cites AT\&T's response to the establishment of COMSAT, which was to develop optical transmissions.) The change represented by divestiture for Bell Labs is merely in the way it benefits from successful research; before, it was mainly through cross-licensing agreements (the old AT\&T was forbidden from benefiting directly from spin-off from its research), while now "one can envisage a script where AT\&T cannot afford to pay its dividend". The effect is that research has "moved from being an important part of AT\&T's prospects to a vital part"

Laboratory managers have been told to work harder to identify promising research breakthroughs at an early stage in order to alert promising development workers; while the development division has been totally reorganized into product line groupings that correspond to the activities of AT\&T's other subsidiaries. Before divestiture, a researcher who found a result of possible interest would "write a memo, throw it over a wall and wait for someone to answer", according to David Lang, head of semiconductor and electronics research: "Now they answer the telephones".

Penzias says the salary scheme for basic researchers at Bell Labs continues to encourage excellence in research, which is 
assessed and closely monitored by laboratory managers. (Efforts by researchers to ensure that their ideas are taken up by development staff are, however, now rewarded by salary bonuses, an innovation to reflect the changing times.) And Penzias believes in allowing researchers total freedom of inquiry. Mitchell Marcus, a linguistics and artificial intelligence researcher, agrees that he is given "more freedom than in a university". Alan Huang, who heads what may be the only corporate optical computing research department in the world, says he was "startled" shortly after divestiture to be told to take more risks in his research.

Huang's futuristic theorems on pattern recognition algorithms that might one day form the basic logical operations in optical computers are clearly exceptional, but his upbeat assessment of the post-divestiture working environment at Bell Labs is shared by many others. However, there is a niggle: Bell Labs have made a decision to be more careful about the information they will allow researchers to publish.

The irritation arises because recognition by peers is an important form of feedback, not entirely compensated for by the knowledge that permission to publish is being denied because of the possible importance to AT\&T of the results being reported. Ross says he favours publishing more, but with "more on what we've done and less on how we did it". Fewer than one per cent of the 4,000 papers submitted for publication clearance each year are turned back for revision, but it seems to be accepted that irritation over this has increased: Ross says he is watching the subject "closely". Penzias cites the case of Narendra Karmarkar's celebrated algorithm in linear programming, now being used by AT\&T for designing Pacific basin communication networks, as an example of the successful and judicious application of the policy: although Karmarkar's particular implementation of the algorithm remains proprietary, enough details were released for publication for Karmarkar to receive public recognition and win academic prizes.

Ross opposed divestiture at the time the question was being examined in court, and says he still believes the decision was a mistake. But it has allowed - or obliged - Bell Labs to be more responsive to technical developments. Ross complains that Bell Labs' most famous invention, the transistor, was brought into every home in transistor radios by other companies while AT\&T spent 20 years in developing a version reliable enough for use in its only permitted application: telephone switching equiment. When the next "transistor" is invented, Ross says, "we can take it wherever we want". And, perhaps with good reason, he seems to have no doubt that there will be a next time.

Tim Beardsley

Israeli-Egyptian cooperation

\section{Minor relic of Camp David}

Rehovot

THE grandiose dreams of large-scale scientific cooperation between Egypt and Israel that flowered in the wake of Anwar Sadat's visit to Jerusalem in November 1977 and the peace treaty of March 1979 have not materialized. Nevertheless, despite intervening political storms, joint research projects in agriculture, mariculture and medicine have been quietly taking place.

As with the Camp David negotiations, US go-betweens have played an important role; the trilateral Cooperative Arid Lands Agriculture Research Programme (CALAR) was set up by researchers from Egypt, Israel and the United States at the University of San Diego, California, in June 1981, with financial support from the US Agency for International Development.

Although research programmes are developed and carried out independently in each participating country to suit specific conditions and needs, experience has shown that lessons learned in one are generally applicable in the other. This is certainly true of the exploitation for agricultural purposes of the abundant quantities of saline water in both Israel and Egypt.

One of the participating scientists, Professor Jehoshua Rudich of the Hebrew University's Faculty of Agriculture in Rehovot, points out that the Israeli practice until now has been to dilute saline water found in its desert regions (normally some five times as salty as ordinary irrigation water) with fresh water until it is only twice as saline. It is then used to irrigate salt-tolerant crops, notably cotton and melons.

More recently, within the framework of the CALAR programme, undiluted brackish water has been used to grow tomatoes (following the use of small quantities of sweet water to reach the flowering stage). The yields were slightly below normal, but the tomatoes were of high quality colour, acidity and flavour.

In parallel work in Egypt, Dr Adel S. El-Beltagy and his colleagues have shown, according to a recent CALAR report, that the local Edkawy variety of tomato is highly suitable for cultivation with saline water. They are, at the same time, producing water of various degrees of salinity and testing it with different methods of irrigation (drip, furrow), as well as studying how yields are affected by such factors as planting distances, windbreaks and fertilizers.

Another CALAR project in both countries involves the development of droughtresistart forage shrubs to feed sheep and goats. While the exploitation of brackish water is naturally emphasized, Dr Dov Pasternak of Israel's Ben-Gurion University, has set his sights on using water taken directly from the Mediterranean. His team has achieved encouraging results with approximately 50 plant species, most of them from the parched interior of $\mathrm{Au}$ stralia.

The Egyptians, meanwhile, have achieved significant progress in crossbreeding the Barki goat, a hardy native of their desert regions but a low producer of milk, with the high-producing Damascus goat.

A third sphere under investigation is the cultivation of crops that can be used as industrial raw materials. Successful results have been achieved in the deserts of both countries with jojoba, guayule and buffalo gourd.

Although political factors have kept cooperation out of the headlines, it has been reflected in more than a dozen joint Israeli-Egyptian presentations at international gatherings as well as joint papers in international scientific journals, mostly on the endemic parasitic afflictions leishmaniasis and malaria.

Medical cooperation began, however, with the mosquito-borne viral disease called Rift Valley fever. Ordinarily confined to central and southern Africa, it has killed 598 people and thousands of animals in Egypt since 1978. Israeli experts, fearing a further spread of the disease, readily agreed to a suggestion by the United States of discussions with their Egyptian counterparts.

Israel's main contribution has been made by a team led by Professor Rachel Galun of the Hebrew University's Kuvin Centre for the Study of Infectious and Tropical Diseases, which carried out studies on the behaviour of the mosquitoes that transmit the virus to cattle, sheep and man. Her findings were almost certainly of use in helping Dr Sherif El-Said of Ain Shams University and his colleagues in their successful efforts first to monitor and then to stamp out Rift Valley fever in Egypt.

Hebrew University researchers also worked together with Egyptian doctors and scientists after an outbreak of visceral leishmaniasis in Egypt. On that occasion, efforts in Jerusalem centred on the detection of antileishmanial antibodies by use of a new method that was developed there.

"Like all good cooperation", Professor Galun explains, "that between the Egyptians and ourselves has been based on mutual self-interest. For we both realize that infectious diseases and the vectors that carry them do not respect national boundaries." 